\title{
Intellectual and personality factors in the achievement of high exam effectiveness in first-year Russian university students
}

\author{
Olesya Yu. Gorchakova, Valeria V. Matsuta, Sergey A. Bogomaz \\ Faculty of Psychology, National Research Tomsk State University, Tomsk, Russia \\ *Corresponding author. E-mail: bogomazsa@mail.ru
}

The goals set forth in regulatory documents for the development of Russian education presuppose quantitative evaluation of factors and conditions that ensure students' achievement of high competence, personality development, and self-realization. Evaluation of intellectual and personality characteristics of first-year university students and study of the relationship among these characteristics thus become important tasks.

The research objective was to evaluate relationships among social and abstractlogical types of intelligence, personality characteristics, and exam effectiveness (performance).

The study sample was made up of 900 first-year university students $(55.2 \%$ female and $44.8 \%$ male) from Tomsk State University who filled in paper-and-pencil forms in Russian: The Evaluation of Choice in Conflict Situations Questionnaire, Raven's Progressive Matrices, the Self-Organization of Activity, the Reflexivity Type Assessment Test, the Self-Determination Scale, the Satisfaction with Life Scale, and the World Assumptions Scale. Scores on the Unified National Examination in Mathematics (UNE in Mathematics) and the first exam results at the university were used to measure academic performance. The data were statistically processed using descriptive analysis, correlation analysis, and factor analysis.

The preference for compromising and collaborating strategies indicates a high level of social intelligence and contributes to socio-psychological adaptation of young people to conditions of university education that are new to them, which require greater independence and activity. Social intelligence and abstract-logical intelligence are relatively independent intelligence types.

Social intelligence and personality characteristics are not determinants of scores on the UNE in Mathematics. Probably the process of educating students in mathematics in the graduating classes of Russian secondary schools is replaced by training to solve problems on the UNE, so that students' individual characteristics in preparation for the test are no longer factors that influence exam effectiveness. A disparity between social and abstract-logical types of intelligence is accompanied by low academic effectiveness. Proportional development of social and abstract-logical types of intelligence may be an important factor in achieving high academic effectiveness.

Keywords: social intelligence, abstract-logical intelligence, academic achievement, personality characteristics, higher professional education 


\section{Introduction}

A number of studies have shown that there is no general agreement on the nature and definition of intelligence among scientists. Existing approaches to intelligence as an object of study are inconsistent. At the same time, around the world shows that personality and the intellect are major factors of social development amid constant economic and socio-cultural transformations. Many examples show that the more people use their intelligence, the more successful and sought-after they are in various spheres of life.

R. Lynn and T. Vanhanen report on studies that prove the correlation among intelligence, income, and socio-economic status (Lynn \& Vanhanen, 2006). P.A. Freund and H. Holling have proven that intelligence, openness, conscientiousness, and neuroticism significantly predetermine current achievement motivation. Persons with high intelligence show higher motivation and more confidence in their self-realization (Freund \& Holling, 2011). S. Kanazawa believes that more intelligent people are more likely to acquire and pass on evolutionarily new preferences and values (Kanazawa, 2012). B.J. Pesta, M.A. McDaniel, and S. Bertsch point out a high correlation between intelligence and the general welfare of an administrativeterritorial unit (an American state) $(\mathrm{r}=0.83)$, as well as a correlation between the welfare of the state and the prevalence of liberal attitudes in the state (Pesta, McDaniel, \& Bertsch, 2010).

Recent developments in psychological science show a notable popularity of studies examining types of intelligence, especially social intelligence. G. Allport, E. Vernon, J. Guilford, O. John, S. Kosmitsky, and G.P. Geranyushkina consider social intelligence to be a special type of intelligence that is independent of general intelligence. In accordance with the current concepts of most scientists, we can say that a high level of social intelligence determines a person's effectiveness, social adaptability and success, and leadership capabilities (Kunitsyna et al., 2001; Savenkov, 2005, 2009; Sternberg, 2003).

The relationship between social intelligence and other types of intelligence (general, emotional, and academic) is very important. Resolving this question is non-trivial because of the extreme difficulty of measuring social intelligence, given its high context-dependence and ontological content (Luneva, 2012). The relationship between social intelligence and the personality characteristics that determine a person's effectiveness (basic beliefs about the nature of the world and about one's own abilities, purposefulness, inclination for planning and reflection on one's activity) has so far been little studied.

We believe that the relevance of the relationship between different intelligence types and the role of social intelligence in a person's achievement of high effectiveness has significantly increased because of the reforms which are being carried out in Russia in secondary and higher education. The goals set forth in regulatory documents for Russian education presuppose the quantitative evaluation of factors and conditions that ensure students' high competence, personality development, and self-realization (Abakumova \& Bogomaz, 2015). Evaluation of the intellectual and personality characteristics of students in the first year of higher education and study of the relationship among these characteristics thus become important tasks. 
We initiated this study with a group of first-year students to achieve two main objectives: to calculate mean values for social and abstract-logical intelligences, and to evaluate relationships among different types of intelligence, personality characteristics, and exam effectiveness.

We hypothesized that different types of intelligence and the personality characteristics of the students make different contributions to high academic achievement. This would lead one to expect that the relationship between students' intellectual and personality characteristics would manifest itself as much as possible in such difficult situations as the Unified National Examination and the first exam at university. This is a new life situation for students, one that requires new professional and personality competencies. For this reason, we chose first-year students to participate in our study.

\section{Method}

\section{Sample}

The sample was made up of 900 first-year university students from different departments (faculties) of Tomsk State University. There were 260 students specializing in the natural sciences (Faculty of Chemistry, Faculty of Geology and Geography, Biological Institute), 290 in technical specialties (Faculty of Physics, Faculty of Radiophysics, Faculty of Mechanics and Mathematics, Faculty of Informatics), 450 students in the humanities (Faculty of Psychology, Faculty of Philosophy, Faculty of Philology, International Management Faculty, Higher School of Business, Faculty of History, Institute of Law). The average age of study participants was $18.5 \pm$ 1.94 years (mean and standard deviation). The participants were $55.2 \%$ female and $44.8 \%$ male.

\section{Study instruments}

To examine the study participants' social intelligence, we applied the Evaluation of Choice in Conflict Situations Questionnaire developed by Russian psychologist Sergey Shcherbakov, based on the Thomas-Kilmann Conflict Mode Instrument (Shcherbakov, 2010). This instrument takes into account the idea that social intelligence vividly manifests itself in difficult or conflict situations. It is a 20-item questionnaire with 7 subscales: Competing, Accommodating, Avoiding, Compromising, Collaborating, Recourse to the mediator, and Giving Caustic Remarks.

In other studies we have shown that high scores for the strategies Compromising and Collaborating or low scores on the strategies Competing, Recourse to the mediator, Giving Caustic Remarks, Avoiding, and Accommodating can indicate the level of social intelligence (Sheketera, Sudneva, \& Bogomaz, 2014). Thus we calculated the Social Intelligence index as the arithmetical mean the scores for the Collaborating and Compromising strategies (Sudneva, Karakulova, \& Bogomaz, 2010).

A modification of the Raven's Progressive Matrices was applied (Koichu, 2003) to examine abstract-logical intelligence. The number of tasks was reduced to 30 matrices, and only even tasks of the original test were used. Testing time was not limited by us, but the time the student required for the test was recorded in order 
to calculate the intellectual effectiveness and productivity of the study participants. Intellectual effectiveness was calculated as a sum of the points for correctly solved tasks according to the test instructions. Intellectual productivity was calculated as a ratio of the total score for correctly solved tasks to the time required for the test, multiplied by 100 .

We hypothesized that the ratio of social and abstract-logical intelligences may contribute to the individuality of first-year students. To estimate this ratio, we calculated two ratios, the numerator of which was the Social Intelligence index and the denominator of which was either Effectiveness or Productivity as shown on the Raven's test.

To measure participants' academic effectiveness, we used their scores on the Unified National Examination in Mathematics and their first exam results at the university. It should be noted that in Russia the UNEs for school leavers are now considered as university entrance examinations. Mathematics is one of two compulsory disciplines that are tested.

To examine study participants' personality characteristics that are most related to self-organization of activity, a set of questionnaires including a number of subscales was applied (Bogomaz \& Matsuta, 2010; Atamanova \& Bogomaz, 2011b). This instrument incorporates the Self-Organization of Activity Questionnaire developed by E.Yu. Mandrikova, with the Purposefulness Index and Rationality Index (Mandrikova, 2007); the Reflexivity Type Assessment Test by D.A. Leontiev (Leontiev et al., 2009); the Self-Determination Scale by K. Sheldon (1995), adapted and modified by E.N. Osin (2010); the Satisfaction with Life Scale by E. Diener (Diener et al., 1985), translated and adapted by E.N. Osin and D.A. Leontiev (Osin \& Leontiev, 2008); and the World Assumptions Scale by R. Janoff-Bulman (1989), translated and adapted by O.A. Kravtsova (Soldatova \& Shaygerova, 2003), with calculation of the total indices for "Benevolence of the World", "Meaningfulness of the World", and "Self-Worth" (Bogomaz, 2014).

\section{Procedure}

Study participants were asked to fill in several paper-and-pencil forms in Russian. We used the Evaluation of Choice in Conflict Situations Questionnaire (Shcherbakov, 2010) to examine social intelligence. This test was performed by 900 first-year students from different faculties of the university. We applied Raven's Progressive Matrices to examine abstract-logical intelligence. This test was performed by only 317 study participants, because of the difficult testing organization that included the individual work with each study participant and adherence to certain specifications. Testing required good quality of Internet and the same way of the testing procedure for all participants. Study participants came to a test center (computer lab) or tested in soil academic buildings on laptops brought testers. Testing was carried out on a computer with Internet access, in Mozilla Firefox. Study participants received an individual login and password to log in for testing to ensure the confidentiality of data, later, in a processing of the data, the login became an individual participant code. Study participants were included in the system and if they were willing to participate, the giving their consent to research in consent form. Then they passed the test to measure the intelligence. 
Mean values of social and abstract-logical intelligence parameters were calculated on the basis of the data collected in a group of first-year students. Social and abstract-logical intelligence parameters were simultaneously evaluated in part of the study sample, as well as personality characteristics and exam effectiveness. This allowed us to analyze the correlations between the parameters under study. The data were organized into a database and statistically processed using descriptive analysis, correlation analysis, and factor analysis in Statistica 6.0 software licensing.

\section{Results}

At the first stage of the study, we calculated mean values for social and abstractlogical intelligence parameters. Statistical results indicated that in case of an interpersonal conflict students prefer such constructive strategies as Compromising and Collaborating. The unconstructive strategy Giving Caustic Remarks is the least preferred (see Table 1).

Table 1. Mean values of parameters of the Evaluation of Choice in Conflict Situations Questionnaire (in points) in a group of first-year students $(n=900)$

\begin{tabular}{lcc}
\hline \multicolumn{1}{c}{ Parameters } & Mean & Standard Deviation \\
\hline Compromising & 97.1 & 15.7 \\
Collaborating & 84.8 & 17.8 \\
Avoiding & 68.6 & 16.5 \\
Competing & 62.7 & 16.7 \\
Accommodating & 62.2 & 16.3 \\
Recourse to the mediator & 58.4 & 15.9 \\
Giving Caustic Remarks & 52.4 & 26.2 \\
Social Intelligence index & 91.0 & 15.4 \\
\hline
\end{tabular}

Note. The social intelligence index is the arithmetical mean between the Collaborating and Compromising strategies.

The developmental level of analytical abilities of first-year students $(n=317)$ that was evaluated using Raven's Progressive Matrices is presented in Table 2.

Table 2. Mean values of parameters of Raven's Progressive Matrices in a group of first-year students $(n=317)$

\begin{tabular}{lcc}
\hline \multicolumn{1}{c}{ Parameters } & Mean & Standard Deviation \\
\hline Intellectual effectiveness (in points) & 103.0 & 23.4 \\
Intellectual productivity (in conventional units) & 18.0 & 6.06 \\
\hline
\end{tabular}

We also calculated means of personality characteristics and basic beliefs in a group of first-year students. These means were within the range of normative values defined by the authors and developers of the instruments used in this study. 
Correlation analysis showed only weak correlations between social and abstract-logical types of intelligence. The maximum value of the correlation was observed between the Compromising strategy and Intellectual Effectiveness on the Raven's test: $\mathrm{r}=0.18 ; \mathrm{p}=0.005 ; \mathrm{n}=254$.

The relationship between social intelligence and personality characteristics was evaluated in a group of first-year students. Correlation analysis showed significant negative correlation between preference for the Avoiding strategy and such parameters as Inclination for Self-Organization of Activity and the Purposefulness index (see Table 3). Students' preference for the Compromising strategy is positively correlated with Systemic Reflection. The preference for the Collaborating strategy is positively correlated with the Inclination for Self-Organization of Activity and Systemic Reflection.

Table 3. Significant correlations between social intelligence parameters and personality characteristic parameters $(\mathrm{n}=792)$

\begin{tabular}{lccc}
\hline \multicolumn{1}{c}{$\begin{array}{c}\text { Personality } \\
\text { characteristics }\end{array}$} & Avoiding & $\begin{array}{c}\text { Social Intelligence } \\
\text { Compromising }\end{array}$ & Collaborating \\
\hline $\begin{array}{l}\text { Inclination for Self- } \\
\text { Organization of Activity }\end{array}$ & $\mathrm{r}=-0.25 ; \mathrm{p}=0.00$ & $\mathrm{r}=0.015 ; \mathrm{p}=0.000$ & $\mathrm{r}=0.28 ; \mathrm{p}=0.00$ \\
$\begin{array}{l}\text { Purposefulness index } \\
\text { Systemic Reflection }\end{array}$ & $\mathrm{r}=-0.30 ; \mathrm{p}=0.00$ & $\mathrm{r}=0.08 ; \mathrm{p}=0.014$ & $\mathrm{r}=0.18 ; \mathrm{p}=0.000$ \\
Rationality index & $\mathrm{r}=-0.09 ; \mathrm{p}=0.005$ & $\mathrm{r}=0.15 ; \mathrm{p}=0.000$ & $\mathrm{r}=0.26 ; \mathrm{p}=0.00$ \\
\hline
\end{tabular}

We used correlation analysis to study the relationship between social and abstract-logical types of intelligence, personality characteristics, and exam effectiveness in mathematics, finding that there were no significant correlations between preference of communicative strategies and scores on the UNE in mathematics. Personality characteristics are also not correlated with UNE scores in mathematics. This may mean that social intelligence and personality characteristics do not make a significant contribution to the achievement of high scores on the UNE in mathematics.

Exam effectiveness on the UNE in mathematics correlates positively with Intellectual Productivity on the Raven's test $(\mathrm{r}=0.27 ; \mathrm{p}=0.00 ; \mathrm{n}=212)$. However, this relationship is weaker than we expected. The relationship between exam effectiveness and Intellectual Productivity turned up to be even weaker $(r=0.13 ; p=0.015)$. Intellectual Productivity is a more important indicator of a high level of abstractlogical intelligence as compared to the indicator of Intellectual Effectiveness.

Correlation analysis also showed that Intellectual Effectiveness and Intellectual Productivity are not correlated with personality characteristics and basic beliefs in the group of first-year students.

Correlation analysis also showed that the ratio, the numerator of which was the Social Intelligence index and the denominator of which was effectiveness of the 
Raven's test, does not correlate with exam effectiveness on the UNE in mathematics, personality characteristics, and basic beliefs. A similar situation is observed with the ratio, the numerator of which was the Social Intelligence index and the denominator of which was Productivity on the Raven's test.

It might be assumed that the absence of significant correlations among intellectual parameters, personality characteristics, and exam effectiveness in mathematics may be associated with the gender of study participants. But correlation analysis carried out separately for the female sample and the male sample did not confirm this hypothesis. Significant correlations between parameters of social and abstractlogical types of intelligence and exam effectiveness in mathematics were absent in both samples (Matsuta, Bogomaz, \& Sudneva, 2014).

The factor structure of the parameters of social and abstract-logical types of intelligence, personality characteristics, and academic effectiveness was studied in a group of first-year students. Eleven indicators were taken into account as a source of data for factor analysis. Principal component analysis with a normalized varimax rotation was conducted in the study sample, which consisted of 129 girls and boys. The number of factors required for the examination was determined using the scree test proposed by R. Cattell. Factor analysis identified 4 factors explaining $60.6 \%$ of the total variance in the correlation matrix. A significant criterion was factor loading greater than 0.50 .

Factor analysis confirmed that exam effectiveness in mathematics is associated only with Effectiveness and Productivity on the Raven's test (see Table 4, Factor 2). The Social Intelligence index is associated only with basic beliefs about Benevolence of the World and Meaningfulness of the World (see Table 4, Factor 4).

Table 4. The factor structure of social and abstract-logical types of intelligence, personality characteristics, and academic effectiveness

\begin{tabular}{lcccc}
\hline \multicolumn{1}{c}{ Parameters } & Factor $\mathbf{1}$ & Factor 2 & Factor 3 & Factor 4 \\
\hline Exam scores in mathematics & 0.04 & $\mathbf{0 . 5 7}$ & 0.27 & 0.33 \\
Intellectual Effectiveness & -0.14 & $\mathbf{0 . 7 8}$ & 0.09 & 0.08 \\
Intellectual Productivity & 0.04 & $\mathbf{0 . 7 8}$ & -0.20 & -0.17 \\
Purposefulness index & $\mathbf{0 . 7 9}$ & -0.12 & 0.20 & -0.15 \\
Rationality index & -0.02 & 0.04 & $\mathbf{0 . 7 9}$ & -0.10 \\
Systemic Reflection & 0.11 & 0.01 & $\mathbf{0 . 6 7}$ & 0.22 \\
Benevolence of the World & 0.45 & -0.04 & -0.14 & $\mathbf{0 . 5 8}$ \\
Meaningfulness of the World & 0.04 & -0.09 & 0.08 & $\mathbf{0 . 7 1}$ \\
Self-Worth & $\mathbf{0 . 8 1}$ & -0.00 & 0.12 & 0.18 \\
Self-Determination & $\mathbf{0 . 8 0}$ & 0.03 & -0.14 & 0.15 \\
Social Intelligence index & 0.00 & 0.31 & 0.10 & $\mathbf{0 . 6 4}$ \\
Explained variance & 2.16 & 1.67 & 1.31 & 1.52 \\
Percentage of total explained variance & 0.20 & 0.15 & 0.12 & 0.14 \\
\hline
\end{tabular}


At the second stage of the study, we investigated the relationship among social and abstract-logical types of intelligence, personality characteristics, and academic effectiveness, as measured by students' first exam results at the university. In university education, the relationship between exam effectiveness and the parameters under study changes compared to earlier years. Personality characteristics and social intelligence of first-year students become significant factors in the achievement of high exam effectiveness (or high marks on the exam). This pattern is particularly clearly manifested in the group of first-year students of the Faculty of Radiophysics (see Table 5).

Table 5. Significant correlations between exam scores in mathematics and physics, and social intelligence and personality characteristics in the group of first-year students of the Faculty of Radiophysics ( $\mathrm{n}=38)$

\begin{tabular}{llc}
\multicolumn{1}{c}{\begin{tabular}{c} 
Social Intelligence \\
\multicolumn{1}{c}{ and Personality Characteristics }
\end{tabular}} & Mathematics & Physics \\
\hline Collaborating & $\mathrm{r}=0.34 ; \mathrm{p}=0.04$ & $\mathrm{r}=0.32 ; \mathrm{p}=0.05$ \\
Inclination for Self-Organization of Activity & $\mathrm{r}=0.43 ; \mathrm{p}=0.01$ & $\mathrm{r}=0.35 ; \mathrm{p}=0.03$ \\
Purposefulness index & $\mathrm{r}=0.40 ; \mathrm{p}=0.01$ & $\mathrm{r}=0.29 ; \mathrm{p}=0.08$ \\
Rationality index & $\mathrm{r}=0.38 ; \mathrm{p}=0.02$ & $\mathrm{r}=0.34 ; \mathrm{p}=0.04$ \\
Meaningfulness of the World & $\mathrm{r}=0.33 ; \mathrm{p}=0.04$ & $\mathrm{r}=0.43 ; \mathrm{p}=0.01$ \\
Self-Worth & $\mathrm{r}=0.37 ; \mathrm{p}=0.02$ & $\mathrm{r}=0.23 ; \mathrm{p}=0.17$ \\
Self-Determination & $\mathrm{r}=0.19 ; \mathrm{p}=0.27$ & $\mathrm{r}=0.37 ; \mathrm{p}=0.02$ \\
\hline
\end{tabular}

According to Table 5, students' first mathematics and physics exam scores are associated with such personality characteristics as Inclination for Self-Organization of Activity, Purposefulness, Rationality, Self-Determination, Meaningfulness of the World, and Self-Worth.

The more the first-year students of the Faculty of Radiophysics preferred the Collaborating communicative strategy in conflict situations, the higher were their first mathematics and physics exam scores. It is important to note that this correlation was not found among students of other faculties. In the sample group of first-year students of the Faculty of Radiophysics, there is a significant positive correlation between Intellectual Effectiveness on the Raven's test and exam effectiveness in mathematics: $r=0.39 ; p=0.00 ; n=53$. However, in this group of students there is no correlation between Intellectual Effectiveness and the first exam results in mathematics and physics.

In the group of first-year students of the Faculty of Chemistry, there is no significant correlation between intellectual effectiveness on the Raven's test and exam effectiveness in mathematics. However, in this group of students there are correlations between intellectual productivity and the scores on the first exam in general and inorganic chemistry $(\mathrm{r}=0.44 ; \mathrm{p}=0.01 ; \mathrm{n}=30)$ and inorganic chemistry $(r=0.40 ; p=0.03 ; n=31)$. Correlations between exam scores and social intelligence and personality characteristics were not found. 
However, significant correlations were found when analyzing the ratio of social and abstract-logical types of intelligence. The ratio, the numerator of which was Social Intelligence index and the denominator of which was Productivity on the Raven's test, was negatively correlated with the scores in mathematics $(r=-0.46$; $\mathrm{p}=0.03 ; \mathrm{n}=23)$ and chemistry $(\mathrm{r}=-0.46 ; \mathrm{p}=0.04 ; \mathrm{n}=20)$. This means that the stronger the disproportion between social and abstract-logical types of intelligence, the lower the academic effectiveness of first-year students. In this case, the disproportion is a combination of low abstract-logical intelligence and high social intelligence.

In the group of first-year students of the Faculty of Philosophy, there is a weak correlation between Intellectual Productivity on the Raven's test and exam scores in mathematics: $\mathrm{r}=0.26 ; \mathrm{p}=0.05 ; \mathrm{n}=61$. In this group of students there is a correlation between Intellectual Effectiveness on the Raven's test and exam scores in the science of law: $\mathrm{r}=-0.32 ; \mathrm{p}=0.05 ; \mathrm{n}=40$.

Exam scores in history revealed negative correlations with Accommodating $(\mathrm{r}=-0.50 ; \mathrm{p}=0.01 ; \mathrm{n}=27)$ and with the ratio, the numerator of which was Social Intelligence index and the denominator of which was Effectiveness on the Raven's test $(\mathrm{r}=-0.50 ; \mathrm{p}=0.01 ; \mathrm{n}=26)$. Once again we observe a pattern: The stronger the disproportion between social and abstract-logical types of intelligence, the lower the academic effectiveness of the students.

In the group of first-year students of the Faculty of History, there is a very strong correlation between such parameters of abstract-logical intelligence as Intellectual Effectiveness and Productivity and exam scores. Mathematical disciplines are not in the curriculum of the first term in this Faculty, but correlations between abstract-logical intelligence and exam scores were found in practically all the historical disciplines (see Table 6). Thus, it can be concluded that analytical abilities determine the exam success of these students in almost all historical disciplines.

Table 6. Significant correlations between abstract-logical intelligence and exam scores in the group of first-year students of the Faculty of History

Exam Scores

\begin{tabular}{llllll}
$\begin{array}{c}\text { Abstract-Logi- } \\
\text { cal Intelligence }\end{array}$ & $\begin{array}{c}\text { Contempo- } \\
\text { rary History } \\
\text { of Europe and } \\
\text { America }\end{array}$ & $\begin{array}{l}\text { History of the } \\
\text { Ancient East }\end{array}$ & $\begin{array}{c}\text { History } \\
\text { of Russia }\end{array}$ & Archaeology & $\begin{array}{c}\text { History of } \\
\text { Primitive } \\
\text { Society }\end{array}$ \\
\hline Intellectual & $\mathrm{r}=0.45 ;$ & $\mathrm{r}=0.51 ;$ & $\mathrm{r}=0.18 ;$ & $\mathrm{r}=0.51 ;$ & $\mathrm{r}=0.45 ;$ \\
Effectiveness & $\begin{array}{l}\mathrm{p}=0.01 ; \\
\mathrm{n}=35\end{array}$ & $\begin{array}{l}\mathrm{p}=0.01 ; \\
\mathrm{n}=29\end{array}$ & $\begin{array}{l}\mathrm{p}=0.26 ; \\
\mathrm{n}=29\end{array}$ & $\begin{array}{l}\mathrm{p}=0.02 ; \\
\mathrm{n}=21\end{array}$ & $\begin{array}{l}\mathrm{p}=0.04 ; \\
\mathrm{n}=21\end{array}$ \\
Intellectual & $\mathrm{r}=0.32 ;$ & $\mathrm{r}=0.63 ;$ & $\mathrm{r}=0.35 ;$ & $\mathrm{r}=0.64 ;$ & $\mathrm{r}=0.60 ;$ \\
Productivity & $\begin{array}{l}\mathrm{p}=0.06 ; \\
\mathrm{n}=35\end{array}$ & $\begin{array}{l}\mathrm{p}=0.00 ; \\
\mathrm{n}=29\end{array}$ & $\begin{array}{l}\mathrm{p}=0.03 ; \\
\mathrm{n}=29\end{array}$ & $\begin{array}{l}\mathrm{p}=0.00 ; \\
\mathrm{n}=21\end{array}$ & $\begin{array}{l}\mathrm{p}=0.00 ; \\
\mathrm{n}=21\end{array}$ \\
\hline
\end{tabular}

Correlations between exam scores and the preference of communicative strategies were not found in the group of first-year students of the Faculty of History.

However, a correlation was shown between the ratio, the numerator of which was Social Intelligence index and the denominator of which was Productivity on 
the Raven's test, and exam scores in history of the Ancient East $(\mathrm{r}=-0.49 ; \mathrm{p}=0.01$; $\mathrm{n}=26)$, archaeology $(\mathrm{r}=-0.54 ; \mathrm{p}=0.01 ; \mathrm{n}=20)$, and history of primitive society $(\mathrm{r}=0.55 ; \mathrm{p}=0.01 ; \mathrm{n}=20)$. This allows us to point out a pattern: the disparity between social and abstract-logical types of intelligence accompanied by low academic effectiveness.

Weak correlations were found only between exam scores in the history of Russia and some personality characteristics of students of the Faculty of History (see Table 7).

Table 7. Significant correlations between exam scores in history of Russia and personality characteristics in the group of first-year students of the Faculty of History $(n=63)$

\begin{tabular}{lc}
\hline Personality Characteristics Parameters & Exam Scores in History of Russia \\
\hline Purposefulness index & $\mathrm{r}=0.27 ; \mathrm{p}=0.03$ \\
Systemic Reflection & $\mathrm{r}=0.25 ; \mathrm{p}=0.05$ \\
Life Satisfaction & $\mathrm{r}=0.25 ; \mathrm{p}=0.05$ \\
\hline
\end{tabular}

These facts suggest that exam scores in the history of Russia are connected with such personality characteristics of first-year students of the Faculty of History as Purposefulness, Rationality, and Life Satisfaction. In other words, personality characteristics of students (on a par with intelligence parameters) are important factors in achieving high exam effectiveness.

\section{Discussion}

In our study, we had set a goal to calculate mean values of social and abstract-logical intelligence parameters, and to evaluate relationships among different types of intelligence, personality characteristics, and exam effectiveness in a group of firstyear students.

The calculated mean values of social and abstract-logical types of intelligence in a group of first-year students presented in Tables 1 and 2 may be taken into account in the monitoring of educational effects in the university, as well as in the design of experiments studying the brain processes that underlie intellectual activity.

The findings of previous studies analyzing and evaluating social and abstractlogical intelligence, personality characteristics, and basic beliefs of first-year students, suggest a quite high potential of girls and boys who have entered university (Sudneva, Karakulova, \& Bogomaz, 2013).

Our results show that students prefer constructive communicative strategies, Compromising and Collaborating, in case of conflict. The unconstructive strategy Giving Caustic Remarks is the least preferred. This indicates a high level of social intelligence. We believe that this preference may contribute to socio-psychological adaptation of young people to the new conditions of university education, which require greater independence and activity. This raises the question: "Does this adaptation increase or decrease in the process of university education?"

An important question for us was the relationship between social and abstractlogical types of intelligence. The data show that social intelligence and abstract-log- 
ical intelligence are relatively independent types of intelligence in the pre-adult age. The combination of these types of intelligence can determine unique individual and typological characteristics of girls and boys. This uniqueness can be increased at the expense of possible relationships between intellectual abilities and basic beliefs, and personality characteristics that are the most related to activity: Purposefulness, Inclination for Planning and Self-Organization of Activity, Systemic Reflection, and Life Satisfaction. The data show that abstract-logical intelligence does not correlate with the above-listed personality characteristics of the girls and boys. On the contrary, it was found that the higher the social intelligence, the greater the Purposefulness, Rational Attitude to Activity, Inclination for Self-Organization of Activity, and Systemic Reflection. In other words, high social intelligence of the students correlates positively with those of their personality characteristics that are responsible for self-regulation of activity (Matsuta \& Bogomaz, 2014). On the other hand, students who prefer to avoid solving interpersonal problems in case of conflict (which is an indicator of low social intelligence), tend to have low Purposefulness and low Inclination for Self-Organization of Activity.

It is important to emphasize that the correlation analysis shows that social intelligence is correlated with psychological security and with such basic beliefs as Self-Worth. This indicates that the stronger the students' ability to navigate interpersonal relations and communicative regulations, and the more the students are prepared to collaborate (which is an indicator of high social intelligence), the more they feel psychological security and the more they appreciate their own personalities.

Another important question for us in this study was about the degree of influence of different intelligence types and personality characteristics on exam effectiveness. Based on published data, social and abstract-logical types of intelligence and personality characteristics may be considered as determinants of academic performance and exam effectiveness. However, correlation and factor analysis showed that only abstract-logical intelligence was in some degree associated with exam effectiveness in mathematics.

Social intelligence and personality characteristics are not correlated with scores on the UNE in mathematics in the Russian educational system. That is, they are not its determinants. These findings are consistent with those of another study: Yu.A. Dodonova and T.N. Tikhomirova showed that social intelligence of schoolchildren is not correlated with their school performance (Dodonova \& Tikhomirova, 2010).

This may be explained by the fact that the educational process in graduating classes of Russian secondary schools is replaced by a training process aimed at solving problems on the UNE. Many school teachers and educational specialists point out this fact (Bazarov \& Shevchenko, 2012; Abakumova \& Bogomaz, 2015).

In this "teaching to the test", teachers may regard schoolchildren's personalities as negative factors which they need to neutralize, as became clear from interviews with schoolteachers. As a consequence, the relationship between intellectual and personality characteristics and exam effectiveness may be lost. But, as the results of our study have shown, in the process of such training the relationship between schoolchildren's exam effectiveness and intellectual abilities can be significantly weakened. If our reasoning is correct, the question arises, "What does the UNE 
measure?" We can hypothesize that the UNE largely shows not schoolchildren's personal achievements, but the organizational quality of the training process for taking the UNE.

Contrariwise, under conditions of university education, when the subjects of educational activity are provided with significant self-dependence and none of the teachers trains students for their exams, the relationships between exam effectiveness, on the one hand, and intellectual abilities, personality characteristics, and basic beliefs, on the other, changes significantly compared with secondary school.

In other words, the individuality of university students plays an essential role in achieving high exam effectiveness. Moreover, their social and abstract-logical types of intelligence, personality characteristics, and basic beliefs become significant.

This pattern is manifested, for example, by students' first exam results at university. Students of the Faculty of Radiophysics have a particularly high significant positive correlation between Intellectual Effectiveness on the Rave's test and exam effectiveness in mathematics.

In the sample group of first-year students of the Faculty of Chemistry, there is a correlation between Intellectual Effectiveness and their first exam results in general and inorganic chemistry.

It was found that social intelligence of first-year students in certain cases becomes a significant factor in the achievement of high scores on mathematics and physics exams. It is significant to note that the ratio of the different intelligence types contributes to the achievement of high scores during the exam. It was further found that the stronger the disparity between social and abstract-logical intelligences (or the more social intelligence has developed compared to abstract-logical intelligence), the lower the exam effectiveness of first-year students.

Exam scores in some disciplines are connected with such personality characteristics of first-year students as Inclination for Self-Organization of Activity, Purposefulness, Rationality, Self-Determination, Life Satisfaction, Meaningfulness of the World, and Self-Worth.

Analysis of the relationship between social and abstract-logical types of intelligence, and academic effectiveness, found that the disproportion between social and abstract-logical intelligence types was accompanied by low academic effectiveness of students. This means that the proportional development of social and abstractlogical types of intelligence may be an important factor in achieving high exam effectiveness.

\section{Conclusion}

This study provided additional evidence for the assertion that social intelligence and abstract-logical intelligence can be regarded as relatively independent intelligence types. The study also clarified the role of intellectual and personality factors in achieving high exam effectiveness of girls and boys in the modern Russian educational system. This is the theoretical significance of the study.

The data show various patterns in relation to exam effectiveness at school and university. Thus, social intelligence and personality characteristics are not related 
to exam effectiveness in mathematics, and the role of students' analytical abilities in achieving high exam results is not as high as would be expected. Therefore, we hypothesized that individual characteristics of students, in their training to take the UNE exam, are no longer factors that influence exam effectiveness.

On the other hand, not only the students' analytical abilities, but also their high social competence, the disproportion in social and abstract-logical intelligence types, and some personality characteristics are important factors in learning activity and affect the performance of students at the university.

We are continuing to conduct research in this direction. In particular, we are collecting empirical evidence that social, emotional, and abstract-logical types of intelligence are relatively independent intelligence types (Bogomaz \& Gorchakova, 2015). In addition, on the basis of our findings, we have formed different functional groups among students with high and low intellectual abilities, and started a series of experiments with EEG and eye-tracking. The object of these experiments is to identify the brain activity of subjects with different degrees of manifestation of social and abstract-logical intelligence types. The first empirical results have been published (Bocharov, Bogomaz, Savostyanov et al., 2015).

The main practical significance of our study is the opportunity to develop an optimal algorithm for evaluating psychological characteristics of girls and boys who have entered university, and a psychological monitoring algorithm for educational effects at university in accordance with the new Russian Federation Law "On Education".

\section{Limitations}

A limitation of this study is the use of intelligence techniques developed on the basis of various theoretical concepts (Raven's Progressive Matrices and Shcherbakov's Questionnaire). However, at the present time no group of scientists is trying to create a unified paradigm of tests for social, emotional, and abstract-logical types of intelligence.

\section{Acknowledgements}

This study was supported by the Russian Foundation for Humanities grant (project No. 15-36-01374) “The study of search activity under the conditions of cognitive activity by using system of oculomotor activity registration (eye-tracker) and electroencephalography".

\section{References}

Abakumova, N.N., \& Bogomaz, S.A. (2015). Monitoring obrazovatelnykh rezultatov v vuze: Problema soderzhaniya psikhologo-pedagogicheskoy diagnostiki [Monitoring of educational outcomes in the university: The problem of the content of psycho-pedagogical diagnostics]. Psikhologiya obucheniya [Journal of Educational Psychology], 3, 62-68.

Allport, G.W. (1937). Personality: A psychological interpretation. New York, Henry Holt \& Company.

Atamanova, I.V., \& Bogomaz, S.A. (2011). Personal and communicative potential of technically oriented young people in the globalized world, Journal of the Worldwide Forum on Educa- 
tion and Culture, 3, 12-22. Retrieved from http://www.theworldwideforum.org/resources/ WWFEC+Issue+3.pdf

Bazarov, T.Yu., \& Shevchenko, Yu.S. (2012). Nuzhna li psikhologicheskaya podgotovka k sdache EGE? [Is psychological preparation needed to pass the UNE?]. Retrieved from http://jarki. ru/wpress/2012/04/05/3017

Bocharov, A.V., Bogomaz, S.A., Savostyanov, A.N., Knyazev, G.G., Budakova, A.V., Zaleshin, M.S., \& Astakhova, T.N. (2015). Clustering of independent components of the EEG in determining individual characteristics of reactions related to a moral choice. 2015 International Conference on Biomedical Engineering and Computational Technologies (SIBIRCON 2015): Conference Proceedings (pp. 34-40). New York: IEEE.

Bogomaz, S.A., \& Gorchakova, O.Yu. (2015). Sootnosheniye raznykh vidov intellekta kak predmet nauchnogo spora i izucheniya [The ratio of different intelligence types as a matter of scientific dispute and study]. Vserossiyskaya nauchnaya konferentsiya, posvyashchennaya 60-letiyu so dnya rozhdeniya V.N. Druzhinina: Materialy [All-Russian Scientific Conference dedicated to the 60th anniversary of the birth of V.N. Druzhinin: Proceedings] (pp. 37-39). Moscow: Izdatelstvo Institut psikhologii RAN.

Bogomaz, S.A., \& Matsuta, V.V. (2010). Otsenka lichnostnogo potentsiala i vyyavleniye osnovnykh tipov oriyentatsii na professional'nuyu deyatel'nost' u sovremennoy vuzovskoy molodezhi [Assessment of personal potential and determination of basic types of orientation to professional activity of students]. Psikhologiya obucheniya [Journal of Educational psychology], 12, 77-88.

Bogomaz, S.A. (2014). Innovatsionnyy potentsial lichnosti i yego otsenka [Innovative potential of the personality and its evaluation]. Sotsial'nyy mir cheloveka. Materialy V Vserossiyskoy nauchno-prakticheskoy konferentsii s mezhdunarodnym uchastiyem "Chelovek i mir: psikhologiya konflikta, neopredelennosti i riska innovatsiy" [Fifth All-Russian scientific and practical conference with international participation "Man and the world: the psychology of conflict, uncertainty and risk innovation": Collection of proceedings] (pp. 275-279). Izhevsk, Russia: ERGO.

Diener, E., Emmons, R., Larsen, R., \& Griffin, S. (1985). The Satisfaction with Life Scale. Journal of Personality Assessment, 49, 71-75. doi: 10.1207/s15327752jpa4901_13

Dodonova, Yu.A., \& Tikhomirova, T.N. (2010). Obshchiy intellekt, sotsialnyy intellekt i kreativnost: struktura i dinamika $\mathrm{v}$ kontekste obrazovatelnoy sredy [General intelligence, social intelligence and creativity: structure and dynamics in the educational environment]. Teoreticheskaya $i$ eksperimentalnaya psikhologiya [Journal of Theoretical and Experimental Psychology], 2, 5-15.

Freund, P.A., \& Holling, H. (2011). Who wants to take an intelligence test? Personality and achievement motivation in the context of ability testing. Personality and Individual Differences, 50(5), 723-728. doi: 10.1016/j.paid.2010.12.025

Geranyushkina, G.P. (2001). Sotsialnyy intellekt studentov - menedzherov i yego razvitiye v usloviyakh formiruyushchego eksperimenta [Social intelligence of management students and its development in a "formative" experiment]. (Unpublished doctoral dissertation). Irkutsk State Academy of Economics: Irkutsk, Russia.

Guilford, J.P. (1967). The nature of human intelligence. New York: McGraw'Hill.

Janoff-Bulman, R. (1989). Assumptive worlds and the stress of traumatic events: Applications of the schema construct. Social Cognition, 7(2), 113-136. doi: 10.1521/soco.1989.7.2.113

Kanazawa, S. (2012). The evolution of general intelligence. Personality and Individual Differences, 53, 2, 90-93. doi: 10.1016/j.paid.2011.05.015

Koichu, B. (2003). Junior high school students' heuristic behaviors in mathematical problem solving. (Unpublished doctoral dissertation). Technion: Haifa. 
Kosmitski, C., \& John, O.P. (1993). The implicit use of explicit conceptions of social intelligence. Personality and Individual Differences, 15, 11-23. doi: 10.1016/0191-8869(93)90037-4

Kunitsyna, V.N., Kazarinova, N.V., \& Pogolsha, V.M. (2001). Mezhlichnostnoye obshcheniye [Interpersonal communication]. St. Petersburg: Piter.

Leontiev, D.A., Lapteva, E.M., Osin, E.N., \& Salihova, A.Z. (2009). Razrabotka metodiki differentsialnoy diagnostiki refleksivnosti [Development of the Reflexivity Type Assessment Test]. VII Mezhdunarodnyy simpozium "Refleksivnyye protsessy i upravleniye": Sbornik materialov [VII International Symposium "Reflexive Processes and Control": Collection of proceedings] (pp. 145-150). Moscow: Kogito Center.

Luneva, O.V. (2012). Kontseptsiya sotsialnogo intellekta lichnosti [The concept of personality's social intelligence]. Znaniye. Ponimaniye. Umeniye [Knowledge. Understanding. Skill], 2, 46-51.

Lynn, R., \& Vanhanen, T. (2006). IQ and global inequality. Augusta, GA, US: Washington Summit Publishers.

Mandrikova, E.Yu. (2007). Oprosnik samoorganizatsii deyatel'nosti [Self-Organization of Activity Questionnaire]. Moscow: Smysl.

Matsuta, V.V., \& Bogomaz, S.A. (2014). Svyaz refleksii i sotsialnogo intellekta u studentov mladshikh kursov issledovatelskogo universiteta [Correlation between reflection and social intelligence of first- and second-year students at a research university]. Sibirskiy psikhologicheskiy zhurnal [Siberian Journal of Psychology], 51, 53-64.

Matsuta, V.V., Bogomaz, S.A., \& Sudneva, O.YU. (2014). Rol intellektualnykh i lichnostnykh faktorov v dostizhenii vysokoy rezultativnosti v YEGE po matematike [The role of intellectual and personality factors in achieving high effectiveness on the UNE in Mathematics]. Sibirskiy psikhologicheskiy zhurnal [Siberian Journal of Psychology], 52, 52-56.

Osin, E., \& Boniwell, I. (2010). Self-determination and well-being. Poster presented at the 4th International Self-Determination Conference. Ghent, Belgium.

Osin, E.N., \& Leontiev, D.A. (2008). Aprobatsiya russkoyazychnykh versiy dvukh shkal ekspressotsenki subyektivnogo blagopoluchiya [Aprobation of Russian versions of the two scales of a rapid assessment of subjective well-being]. III Vserossiyskiy sotsiologicheskiy kongress: $\mathrm{Ma}$ terialy [III All-Russian Congress of Sociology: Proceedings]. Moscow: Institut sotsiologii RAN.

Pesta, B.J., McDaniel, M.A., \& Bertsch, S. (2010). Toward an index of well-being for the fifty U.S. states. Intelligence, 38(1), 160-168. doi: 10.1016/j.intell.2009.09.006

Savenkov, A.I. (2005). Sotsialnyy intellekt kak problema psikhologii odaronnosti i tvorchestva [Social intelligence as the problem of the psychology of giftedness and creativity]. Psikhologiya. Zhurnal Vysshey shkoly ekonomiki [Journal of Higher School of Economics], 2(4), 94-101.

Savenkov, A.I. (2009). Emotsionalnyy i sotsialnyy intellekt kak prediktory zhiznennogo uspekha [Emotional and social intelligences as predictors of life success]. Khimiya $v$ shkole [Chemistry at School], 2, 2-6.

Shcherbakov, S.V. (2010). Diagnostika sotsialnogo intellekta studentov [Diagnosis of student's social intelligence]. Vserossiyskaya zaochnaya nauchno-prakticheskaya konferentsiya "Aktual'nyye voprosy fiziologii, psikhofiziologii i psikhologii": Sbornik nauchnykh statey [AllRussian correspondence theoretical and practical conference "Topical questions of physiology, psychophysiology and psychology": Collection of scientific papers] (pp. 122-126). Ufa, Russia: RITS Bash-IFK.

Sheketera, A.A., Sudneva, O.Yu., \& Bogomaz, S.A. (2014) Stepen vyrazhennosti i analiz vzaimosvyazi abstraktno-logicheskogo i sotsialnogo vidov intellekta u shkol'nikov [Manifestation and correlation analysis of schoolchildren's abstract-logical and social types of intel- 
ligence] Vestnik Tomskogo gosudarstvennogo universiteta [Tomsk State University Journal], 383, 206-211.

Sheldon, K.M. (1995). Creativity and self-determination in personality. Creativity Research Journal, 8, 61-72. doi: 10.1207/s15326934crj0801_3

Soldatova, G.U., \& Shaygerova, L.A. (2003). Praktikum po psikhodiagnostike i issledovaniyu tolerantnosti lichnosti [Workshop on psycho-diagnostics and research on the tolerance of the personality]. Moscow: Moscow University Press.

Sternberg, R.J., Forsyth, G.B., \& Hedlund J. (2002). Prakticheskiy intellect [Practical intelligence]. St. Petersburg: Piter.

Sudneva, O.Yu., Karakulova, O.V., \& Bogomaz, S.A. (2013). Sotsialnyy intellekt v strukture lichnostnogo potentsiala pervokursnikov [Social intelligence in the structure of first-year students' personality potential]. Sibirskiy psikhologicheskiy zhurnal [Siberian Journal of Psychology], 48, 118-126.

Vernon, P.E. (1950). The structure of human abilities. New York: Wiley.

Original manuscript received January 30, 2015

Revised manuscript accepted April 27, 2016

First published online September 30, 2016 